\title{
What is Responsible Lending? The EU Consumer Mortgage Credit Directive in the UK and the Netherlands
}

\author{
Vanessa Mak ${ }^{1}$
}

Received: 18 March 2015 /Accepted: 20 August 2015 /

Published online: 11 September 2015

(C) The Author(s) 2015. This article is published with open access at Springerlink.com

\begin{abstract}
This article assesses if and how the recently adopted EU Directive concerning consumer mortgage credit agreements (Directive 2014/17/EU) contributes to defining a common "responsible lending" policy in the varied contexts of the Member States' mortgage markets. It addresses that question by analysing how the Directive's rules will complement or change the regulatory regimes of the UK and the Netherlands. Drawing on data from economics studies regarding household debt, affordability of credit, and the institutional framework of mortgage market regulation, the article seeks to explain how different regulatory choices in these legal systems are informed by the sources of risk that regulators seek to control. Even with the harmonized rules laid down in the Mortgage Credit Directive, the modalities of "responsible lending" will still differ significantly between EU Member States. Nevertheless, the study of Member States' policies may reveal common concerns and directions on how to address them.
\end{abstract}

Keywords Responsible lending $\cdot$ Mortgage Credit Directive $\cdot$ Consumer protection $\cdot$ Mortgage regulation · Comparative law

\section{Introduction}

The term "responsible lending" has become a moniker for regulatory reforms in consumer credit regulation and has particularly gained new ground in the wake of the global financial crisis. It is now widely accepted that regulation of the financial sector must be "responsible" in the sense that it includes protection against over-indebtedness of consumers (World Bank 2013). In particular, consumers must be protected in the mortgage credit market, where overindebtedness can have severe consequences for consumers - eviction, the loss of their homeand for the stability of the financial system as a whole.

Vanessa Mak

vanessa.mak@uvt.nl

1 Department of Private Law, Room M-310, Tilburg University, P.O. Box 90153, 5000 LE Tilburg, The Netherlands 
This article discusses if and how the recently adopted EU Directive concerning consumer mortgage credit agreements (Directive 2014/17/EU) contributes to defining a common "responsible lending" policy in the varied contexts of the Member States' mortgage markets. ${ }^{1}$ The Directive contains a number of regulatory tools which in most legal systems in the world would be considered duties of "responsible lending": It includes information requirements that should help consumers make better decisions in relation to mortgage credit, duties placing responsibility on lenders to prevent over-indebtedness of consumers, as well as some more prescriptive solutions with regard to loan-to-value (LTV) and loan-to-income (LTI) ratios. ${ }^{2}$ In terms of how such duties are implemented into national regulation, the Directive leaves much room for differentiation between the Member States' laws. Apart from the provisions dealing with the standardized information provided to consumers through the European Standard Information Sheet (ESIS) and with information regarding the Annual Percentage Rate of Charge (APRC), all of the Directive's provisions aim at minimum harmonization rather than full harmonization. ${ }^{3}$ More stringent duties may therefore be adopted or maintained in national laws "in order to avoid adversely affecting the level of protection of consumers relating to credit agreements in the scope of [the] Directive," taking account of differences in market development and conditions in the Member States. ${ }^{4}$

What does this mean concretely for responsible lending policies in the Member States? To what extent do Member States' laws already comply with the EU Directive, and in which other ways have they given shape to responsible lending policies? This article will approach the question through a comparison of mortgage credit regulation in the UK and in the Netherlands. The comparison between both countries is timely, as the adoption of the EU Directive follows closely in the wake of recent reforms of mortgage credit regulation in both Member States. ${ }^{5}$ Notably also, besides the regulatory framework, the effectiveness of policies seeking to promote "responsible lending" is highly dependent on the economic context in which they operate. Interestingly, whilst both countries have a very high ratio of household debt to gross disposable income - approx. $145 \%$ in the UK and $285 \%$ in the Netherlands according to the OECD (n.d.) - the default rate on mortgage payments does not per se correlate to these high numbers. Defaults in the Netherlands after the crisis have been exceptionally low, and even though possession of mortgaged properties increased somewhat more in the UK, here, also, the absolute numbers are low (Scanlon and Elsinga 2014, pp. 340-341). That is notable because earlier studies have indicated that a correlation can exist between a higher household debt ratio and an increase in mortgage arrears (European Commission and Social Situation 2010; Mian and Sufi 2014; Rinaldi and Sanchez-Arellano 2006). An explanation may be found in institutional features of each system, such as tax regimes or government support schemes. ${ }^{6}$ A study of both systems can also reveal which institutional features lend support to a stable housing market, and how a responsible lending policy in regulation fits with these different contexts.

\footnotetext{
${ }^{1}$ Directive 2014/17/EU on credit agreements for consumers relating to residential immovable property [2014] OJ L60/34, recitals 30 and 31. The Directive was adopted on 4 February 2014 and should be implemented by the Member States by 21 March 2016.

${ }^{2}$ For a brief overview of the Directive's provisions, see below, p. 20. The categories of regulatory tools mentioned here correspond to World Bank (2013) at para. 25.

${ }^{3}$ Mortgage Credit Directive, Art. 2.

${ }^{4}$ Mortgage Credit Directive, recital 7.

5 See below "The UK Reforms" and "The Dutch Comparison: More Detailed Modalities for "Responsible Lending","

${ }^{6}$ The focus, conform the analysis by Scanlon and Elsinga (2014), is on formal institutions such as regulation and subsidies. For a discussion of these factors, see "Responsible Lending Policies: Concept and Context".
} 
The structure of this article is as follows. "Responsible Lending Policies: Concept and Context" explores the Directive's concept of responsible lending and sketches which other, institutional factors in the UK and in the Netherlands influence choices made with regard to the regulation of the mortgage market. "The UK Reforms" and "The Dutch Comparison: More Detailed Modalities for 'Responsible Lending"' give a more detailed account of specific regulation in the UK and the Netherlands. "Introducing the EU's Responsible Lending Policy in Dutch and UK Regulation" compares the Dutch and UK approaches, analysing also which aspects of the experiences in both systems may be informative for developing a more detailed common responsible lending policy at EU level. "Conclusion" concludes.

\section{Responsible Lending Policies: Concept and Context}

"Responsible lending" is a policy term. Although it is used to denote a whole range of measures or regulatory tools, ${ }^{7}$ in effect, the term itself does nothing more than to paint with a broad brush the desired goal that the legislator or regulator seeks to achieve. Focusing mainly on inducing responsible behaviour of market participants, the policy is part of a broader context of financial sector management. Policy makers in this area tend to balance several financial sector policy objectives: financial inclusion, stability of the financial sector, integrity of the financial services providers, and financial consumer protection (World Bank 2013, para. $16 \mathrm{ff}$.). This background is reflected also in the Mortgage Credit Directive, which aims to create an internal market for mortgage credit open to all market participants (inclusion), ${ }^{8}$ andin response to the financial crisis - seeks to contribute to the stability of the mortgage market, responsible behaviour by lenders and intermediaries, and high levels of consumer protection. ${ }^{9}$

The policy of "responsible lending" is given hands and feet through more concrete regulatory tools. In many cases, these tools aim at inducing more responsible behaviour in all market participants, lenders, as well as borrowers. A general definition of the policy, consistent with the approach taken by the EU Mortgage Credit Directive, could look like this:

the policy aimed at ensuring responsible behaviour of participants in the financial market - including both lenders and borrowers -, particularly focused on preventing overindebtedness of borrowers, which is given shape through various regulatory mechanisms and which may also be pursued through other legal means, such as remedies in private law, or non-legal means such as education. ${ }^{10}$

Even if the aim of the policy is defined - to prevent over-indebtedness of borrowers - this general definition leaves much room for policy makers to fill in their "responsible lending" policies according to the specific context in which they operate. That is a relevant point to the question whether a common "responsible lending" policy can be defined at EU level that fits the mortgage markets of the various Member States. Looking at the institutional context of Dutch and UK mortgage market regulation, it becomes clear that responsible lending policies are informed by the sources of risk that regulators seek to control. I will briefly describe these

\footnotetext{
$\overline{7}$ See, e.g., the list set out before $\mathrm{n} 2$.

${ }^{8}$ Mortgage Credit Directive, recital 2.

${ }^{9}$ Mortgage Credit Directive, recitals 3-6.

${ }^{10}$ Compare World Bank report (2013), in particular para. 23 and para. 32. The report does not discuss private law liability. That this is a possibility, as well as sanctions in criminal law, is however confirmed in the EU Mortgage Credit Directive, recital 83.
} 
contexts for the Netherlands and for the UK, making some comparative observations between the two countries.

\section{The Dutch Mortgage Market}

The high ratio of household debt to gross disposable income seen in the Netherlands - approx. $285 \%$ in 2012 - could be regarded as a vulnerable spot of its mortgage market (European Commission and Social Situation 2010; Mian and Sufi 2014; Rinaldi and Sanchez-Arellano 2006). Nonetheless, it seems that it is not automatically an indicator that mortgage payment defaults will occur more often in that country. Default rates have in fact been exceptionally low. A survey in 2011 of mortgage agreements with four major lenders revealed that instances in which households were behind with payments - adopting a measure of at least 90 daysamounted to only $0.6 \%$ of mortgage agreements (Kerste et al. 2011, p. 79). Further, most cases in which payment arrears occurred were solved, for example by temporary freezes on interest or relaxing the terms of repayment. Recent studies confirm that the number of defaults on mortgage payments - currently around 100000 - is still low in comparison to the entire number of existing mortgage loans in the Netherlands (BKR 2014; DNB 2014; Expertisecentrum woningwaarde 2014, pp. 11-12). By comparison, in the UK, the number of possessions of mortgaged properties increased significantly between 2006 and 2009, but went down again since then and is still lower than at the previous depth in the housing market cycle in the early 1990s (Scanlon and Elsinga 2014, pp. 340-341).

Dutch regulators are however much aware of the "Janus faced" profile of the Dutch mortgage portfolio. As a recent report by the Dutch central bank emphasizes "[p]ayment arrears and losses on mortgages have remained very limited so far, but the very large mortgage portfolio remains a vulnerability of the Dutch financial system. The large number of underwater mortgages, in particular, will continue to present a latent risk for banks and the government for some time to come" (DNB 2014, p. 7). Current estimates indicate that approximately $30 \%$ of mortgages are "under water"-meaning that the value of the underlying property is lower than the amount of the loan for which the security has been given - which is equal to approximately 1.1 million mortgage loans. ${ }^{11}$ That circumstance not only induces more homeowners to keep their house of the market, even if they were thinking of putting it up for sale. It also means that households are vulnerable to changes, e.g., a decrease in income or a divorce, as a result of which the sale of a house below the value of the mortgage may be inevitable.

It is tempting to conclude on the basis of these figures that the Dutch legislator has been idle in preventing over-indebtedness of households and that the Dutch financial market, even if defaults until now have been low, in consequence is hugely vulnerable to market fluctuations (see, e.g., Dalton 2011). Both conclusions would however be wrong. The Dutch legislator and before then the industry through self-regulation have since long actively sought to limit the risks associated with mortgage loans. In particular — as will be elaborated on in "The Dutch Comparison: More Detailed Modalities for 'Responsible Lending'" — creditworthiness assessments and other tools to prevent over-indebtedness have been part of Dutch mortgage lending

\footnotetext{
$\overline{11}$ The number indicated by $\mathrm{DNB}$, though the number may be lower (950000) if a correction is made for mortgages linked to an investment portfolio; see the letter of the Minister of Housing and the Central Government Sector to the Speaker of the House of Representatives of 5 June 2014. Reactie op Overzicht Financiële Stabiliteit Voorjaar 2014. Available at http://www.rijksoverheid.nl/documenten-en-publicaties/kamerstukken/2014/06/06/ kamerbrief-met-reactie-op-overzicht-financiele-stabiliteit-voorjaar-2014.html.
} 
culture since before the financial crisis. The high rate of household debt, therefore, cannot be attributed to a lax attitude of lenders towards "responsible lending." More plausibly, Dutch households are less vulnerable than this rate suggests, particularly if one takes account of other economic factors. Earlier research has pointed to some specific characteristics of the Dutch mortgage market, such as a tax deduction for interest on mortgage loans (hypotheekrenteaftrek), a government guarantee scheme for low-income borrowers (Nationale Hypotheek Garantie), the social benefits system, the low unemployment rate, the good debt ethic, the relatively modest use of variable interests, and the stable housing market (Kerste et al., p. 28). Other factors that have been named are that the value of all own homes is twice as high as the total mortgage debt and that many Dutch households have pension claims and large private savings that exceed the amount of the debt. ${ }^{12}$ Finally, it should be noted that mortgage debt in the Netherlands appears higher than in other countries because often in international comparisons, no correction is made for so-called endowment mortgages, i.e., mortgages where the payments are placed in a savings account purported to be used for repayment of the entire loan upon the end of its term. ${ }^{13}$ In sum, although concerns about the stability of the mortgage market are not unfounded, the Dutch have within the economic context of their market sought to steer towards a risk-containing strategy for mortgage lending. Considering the latent risk posed by the large number of underwater mortgages, the question remains however whether the prevention of over-indebtedness can be improved by changes in the current regulatory framework.

\section{The UK Mortgage Market}

Like the Netherlands, it would be too much of a generalization to characterize the UK mortgage market solely on the basis of its household debt rates. As we have seen, ${ }^{14}$ a high household debt ratio - in this case $145 \%$ - in practice does not correlate to a higher number of defaults on mortgage payments. In the UK, the low number of defaults has been attributed to low interest rates and lender forbearance (FSA 2012a, b, Datapack, pp. 37-38; Scanlon and Elsinga 2014, p. 341). The Financial Policy Committee (FPC), a sub-committee of the Bank of England's Court of Directors and responsible for the Bank of England's financial stability report, confirms that household debt is not an immediate concern for mortgage regulation in the UK. Practically, this point does seem less of a concern than it is in the Netherlands, since most mortgage loans have a much lower LTV ratio. Whereas Dutch mortgage loans in most cases exceed the value of the property, ${ }^{15}$ in the UK, the ratio is often lower than $90 \%$ or even lower than 75\% (Bank of England 2014, p. 24). The Committee nevertheless indicates that the situation should be monitored: "The FPC does not believe that household indebtedness poses an imminent threat to stability. But it has agreed that it is prudent to insure against the risk of a

\footnotetext{
${ }^{12}$ See the website of the Dutch Central Bureau for Statistics (CBS), http://www.cbs.nl/en-GB/menu/themas/ macro-economie/publicaties/artikelen/archief/2012/2012-3680-wm.htm. But note that the Dutch ratio of gross savings to gross disposable income is just below the EU average and below that of some of the Member States that were bailed out by the EU; see http://epp.eurostat.ec.europa.eu/portal/page/portal/product_details/dataset?p_ product code $=$ TSDEC 240 .

${ }^{13}$ See also the CBS website, http://www.cbs.nl/en-GB/menu/themas/macro-economie/publicaties/artikelen/ archief/2012/2012-3680-wm.htm.

14 Above, "Introduction".

15 Though recent legislation introduces a gradual decrease towards $100 \%$ as the maximum LTV ratio, to be completed by 2018 and henceforth applicable to all new mortgages. See the Temporary rules on mortgage credit of 2011, discussed further below, "The Dutch Comparison: More Detailed Modalities for 'Responsible Lending'",
} 
marked loosening in underwriting standards and a further significant rise in the number of highly indebted households" (Bank of England 2014, p. 52).

Responsible lending policy has in the meantime focused on vulnerabilities of the UK mortgage market in other respects. Recent reforms have focused primarily on introducing more stringent affordability tests, looking at the borrower's income in relation to their committed or essential spending, in order to prevent over-indebtedness. ${ }^{16}$ The FPC more recently indicated that the number of mortgages extended at high(er) LTI multiples (or ratios) has increased and that this can pose risks to the resilience of the UK banking system. Households are in this situation more likely to encounter payment difficulties in the face of shock to income and interest rates (Bank of England 2014, p. 52). Whereas countries like the Netherlands - or in the EU also the Scandinavian countries - already had regulation in place that prevented defaults by focusing on LTI ratios, the UK should perhaps consider more detailed stipulations on this point (Bank of England 2014, pp. 57-58, 63). The suggestion has been made that mortgage lenders should limit the proportion of mortgages at loan to income multiples of 4.5 and above to no more than $15 \%$ of their new mortgages (Bank of England 2014, p. 52).

What these brief descriptions make clear is that the institutional context of national markets has a significant impact on how regulators approach responsible lending issues, in particular where creditworthiness assessments are concerned. Choices to come down on household debt or the affordability of loans for borrowers, and whether to do this by focusing on LTI or LTV ratios or other factors, are much inspired by local concerns. That poses challenges for defining a common "responsible lending" policy at EU level, as becomes clear when we go back to the text of the Mortgage Credit Directive. Recital 55 of the Directive lists a number of factors that can (or should) be taken into account in a creditworthiness test, such as LTI and LTV ratios, but (like Art. 18 of the Directive) adopts a very general level of guidance. The recital moreover explicitly adds that "Member States should be able to issue additional guidance on those or additional criteria and on methods to assess a consumer's creditworthiness, for example by setting limits on loan-to-value or loan-to-income ratios." ${ }^{17}$ One wonders whether it is possible, in the future, to provide more concrete guidance on what a responsible lending policy should look like. To that end, it is worthwhile to study existing approaches in the Member States to better understand which regulatory tools are chosen and how they relate to the institutional context described above.

The next parts consider how the UK and the Netherlands have designed their "responsible lending" policies. I focus in particular on (public) regulation and self-regulation, since the Directive will be implemented as part of these regimes. Private law is also relevant to the regulation of mortgage credit relationships, e.g., as a basis for ex post actions for compensation in cases where lenders have breached a fiduciary duty towards borrowers. However, because of restrictions of scope, private law actions will not be discussed in more detail. ${ }^{18}$

\footnotetext{
${ }^{16}$ This is one of the key changes introduced by the MMR. For a discussion, see "The UK Reforms" below.

${ }^{17}$ The recital further states that Member States "should be encouraged to implement the Financial Stability Board's Principles for Sound Residential Mortgage Underwriting Practices." These principles, also, are general in nature and - although potentially relevant as a source for further harmonization-will not be further discussed here.

${ }^{18}$ For further reading, see, e.g., Cherednychenko 2011; Mak 2013.
} 


\section{The UK Reforms}

Regulation of the mortgage credit market in the UK has, in the wake of the financial crisis, been under reconsideration since 2009. ${ }^{19}$ Following the crisis, the UK legislature has conducted an extensive Mortgage Market Review. Under the aegis of the Financial Services Authority (FSA) - which has now for this part of the market been replaced by the Financial Conduct Authority (FCA $)^{20}$ - a wholesale review of existing regulation was conducted, taking into account available data and consulting relevant stakeholders in the market (e.g., mortgage lenders, intermediaries). The outcome is that a new set of rules has come into force on 26 April $2014 .^{21}$

The Mortgage Market Review (MMR) has been given effect through the FCA rules laid down in the FCA Handbook and more specifically the part dealing with Mortgage Conduct of Business Rules (MCOB). The inclusion of all types of secured credit in this regime is new and widely regarded as an improvement on the pre-existing division of competences. In the earlier framework, the regulation of secured credit fell within two separate regimes (Nield 2012, pp. 162 ff.). Regulated Mortgage Contracts, defined as first legal charges secured upon the borrower's home entered into after 31 October 2004 in the Financial Services and Markets Act 2000 (FSMA), were regulated and supervised by the FSA. ${ }^{22}$ Second charges secured upon the borrower's home, together with unsecured credit, fell within the scope of the Consumer Credit Act 1974 and therefore within the remit of the Office of Fair Trading (OFT). The two regimes for secured credit were merged when the OFT ceased to exist on 31 of March 2013. As of 1 April 2013, the majority of its function moved to the Competition and Markets Authority (CMA) and its competence in enforcing consumer protection law transferred mostly to the Trading Standards Services. ${ }^{23}$ Consumer credit regulation, including all secured credit, from that date falls under the remit of the FCA. The MMR hence has been given effect through the FCA rules laid down in the FCA Handbook and more specifically the part dealing with MCOB.

The new rules make significant changes in relation to responsible lending, placing more responsibility in particularly on lenders to go beyond information disclosure and to take a greater role in assessing the affordability of loans to consumers (compare Nield 2012, pp. 169, 178). This part gives an overview of the development of responsible lending duties in the UK, starting with a brief look at the pre-MMR regime and then moving to the present regulation under the MCOB rules.

\footnotetext{
$\overline{19}$ See http://www.fca.org.uk/firms/firm-types/mortgage-brokers-and-home-finance-lenders/mortgage-marketreview.

${ }^{20}$ The FCA now supervises the conduct of market participants, whereas the supervision of the prudential regulation and supervision of banks, building societies, credit unions, insurers, and major investment firms has been brought under the remit of the Prudential Regulation Authority (PRA). With this model, effective since 1 April 2013, the UK has adopted a so-called twin peaks model of regulation and supervision of the financial market.

${ }^{21}$ Only one provision came into effect earlier, on 26 October 2012. MCOB 11.8.1E is an evidential provision that seeks to protect so-called trapped borrowers, who are unable to leave their current lender. The FSA deemed it advisable to introduce this provision with immediate effect; see FSA (2012a), PS12/16, para. 1.27.

${ }^{22}$ See Financial Services and Markets Act 2000 (Regulated Activities) Order 2001, Art. 61 (as amended).

${ }^{23}$ For a brief overview of the changes, see http://webarchive.nationalarchives.gov.uk/20140402142426/http:// www.oft.gov.uk/about-the-oft/work-and-responsibilities.
} 


\section{"Responsible Lending" Before the Entry into Force of the MMR}

Leading up to the MMR, the UK legislature had already taken some steps towards the introduction of a concept of responsible lending in the broader field of credit (relating to unsecured credit and second charges). The Consumer Credit Act 2006 stipulated that a new s.25(2B) should be included in the Act. This section, dealing with the requirements for lenders to obtain a licence in the UK, provided that the OFT could withhold a licence to lenders who were engaged in business practice "appearing to the OFT to be deceitful or oppressive or otherwise unfair or improper (whether unlawful or not)." ${ }^{24}$ Such business practices, it was specified further, include practices that appear to the OFT to involve irresponsible lending. ${ }^{25}$

The Act did not give further information on what was understood by (ir)responsible lending. To clarify what should be understood by the term, the OFT issued a guidance document in 2010, with further updates in 2011 (OFT 2010/2011). In relation to assessing the affordability of credit to a borrower - an important part of preventing over-indebtedness the document provides some very general guidelines that should be applied to credit agreements regulated by the Consumer Credit Act 1974 (OFT 2010/2011, para. 4.10). Apart from mentioning "the amount of credit to be provided and the associated cost and risk to the borrower," the document does not indicate in more precise terms how the affordability of a loan should be assessed. The guidelines in broad terms mostly point to characteristics of the borrower, such as his "financial situation" and his "credit history." Nevertheless, the guidelines adopt a strongly cautionary tone. Some provisions reflect a high level of caution expected by the OFT, such as guidelines in relation to the impact of changes (unemployment, retirement) on the borrower's ability to repay the loan. Moreover, the list of examples is not exhaustive and creditors are expected to have regard to "both the letter and the spirit" of the guidance (OFT 2010/2011, para. 1.21).

In relation to secured credit, by comparison, for first charges on home's Rule 11 of the MCOB required lenders to take into account the borrower's ability to pay. However, it was left to lenders to develop their own policies against which to determine affordability (Nield 2012, p. 174). The OFT's guidance on second charges only gave general guidelines to lenders which mainly instructed lenders to provide information relevant to the loan and to "encourage" the borrower to consider whether she could afford the credit (OFT 2009, in particular para. 3.14).

\section{Mortgage Market Review}

The weaker points of the UK regulatory framework for mortgage lending came to light and were perhaps the first indicator that stricter lending requirements should be introduced, when the global financial crisis started in 2007. As it turns out, many consumers had been able to obtain mortgages of a value well exceeding the underlying assets - their homes — and without significant difficulty. Empirical studies indicate that prior to the crisis, when the housing market was at its peak, over half of all mortgages were granted without verification of income (FSA 2012a, b, Datapack, p. 59). A significant number of these concerned high LTV mortgage agreements (i.e., agreements where the amount of the loan was high in comparison to the value of the property) and were granted to higher-risk borrower types (FSA 2012a, b, p. 60). In a falling housing market, as well as a prolonged period of economic recession, many borrowers

\footnotetext{
${ }^{24}$ See Consumer Credit Act 2006, s.29.

25 Ibid.
} 
got into financial difficulty. Moreover, the housing market itself stagnated as housing prices dropped and homeowners became more reluctant, or unable, to sell and purchase property. In response to this, the UK government started a consultation in 2009 which resulted in a FSA Policy Statement and final rules in October 2012. ${ }^{26}$

The new rules seek to ensure access to the mortgage market "for the vast majority of customers who can afford it" whilst bringing to an end the poor mortgages practices of previous years (FSA 2012a, b, para. 1.8). Key changes concern stricter duties of responsible lending imposed on lenders, a new requirement that all interactive sales should be advised, and shifting the responsibility for the test of affordability of the credit entirely towards lenders (and no longer imposing it on intermediaries), as well as some changes to information provision which anticipate on the introduction of the EU Mortgage Credit Directive (FSA 2012a, b, Table 1 and para. 1.10).

\section{Rules on Responsible Lending}

Responsible lending is now more specifically defined in the MCOB according to three separate duties (cf. FSA 2012a, b, para. 1.9). First, lenders are required to verify the affordability of a loan for the borrower, ${ }^{27}$ taking into account the borrower's (verified) net income and, as a minimum, the borrower's committed expenditure and basic household expenditure. This duty is part of a wider obligation to determine the suitability of a mortgage for the borrower. ${ }^{28}$ Second, an interest stress test must take account of the impact on mortgage payments of market expectations of future interest rate increases. ${ }^{29}$ And finally, for interestonly mortgages, the lender must ensure that the borrower has an acceptable repayment strategy. $^{30}$

Although the new regulation places more detailed duties on lenders than it did before, leeway is left for lenders to make their own assessment. Initially, the FSA proposed even more exhaustive rules on the requirements that lenders would have to comply with in order to satisfy the norm of responsible lending. Following feedback from the industry, the FSA has opted for a less prescriptive approach (FSA 2012a, Appendix 1). Lenders are to a large extent free to determine for themselves which requirements they will introduce to assess the affordability of loans for borrowers and the conditions for entering into interest-only mortgage agreements.

Notwithstanding this freedom, the rules introduce a number of minimum requirements with which lenders should comply. Section 11.6 sets out minimum requirements for responsible lending and financing, specifying in particular how the assessment of affordability of a mortgage for a borrower should be conducted. Rule 11.6.5R stipulates that, when assessing whether a customer will be able to pay the sums due, the lender must take account of "the income of the customer, net of income tax and national insurance" and as a minimum "the customer's committed expenditure" and "the basic essential expenditure and basic quality-ofliving costs of the customer's household." The rules thus engage with the LTI ratio, even if

\footnotetext{
${ }^{26}$ For the final rules, see FSA (2012a, b), PS12/16. All relevant documentation can be consulted at www.fca.org. uk/firms/firm-types/mortgage-brokers-and-home-finance-lenders/mortgage-market-review.

${ }^{27}$ A general declaration by the customer as to affordability will no longer suffice; see Rule 11.6.6R.

${ }^{28}$ See Mortgage Market Review (Conduct of Business) Instrument 2012, which introduces changes to the $\mathrm{MCOB}$, in this case Rule 4.7A.6.

${ }^{29}$ Rules 11.6.5R(4) and 11.6.18R.

${ }^{30}$ Rule 11.6.41R.
} 
they do not prescribe exact numbers. ${ }^{31}$ They give at least minimum guidance as to the factors that should be taken into account in the affordability assessment, but room for differentiation remains. Earlier studies show that many lenders have some model or methodology to assess the affordability of mortgage credit to a borrower and that they use data from public sources such as the Office for National Statistics (ONS) to estimate expenditure (Oxera 2010, pp. 14 15). Methods nonetheless vary considerably and under the new rules - even if they lay down a minimum - are likely to continue to differ between lenders.

The new rules on responsible lending reflect a significant policy change in consumer mortgage credit regulation. Credit regulation in the UK more generally speaking-including unsecured loans - has traditionally been hesitant to impose ceilings or restrictions on borrowing. The system has tended to pay head to concerns of accessibility of credit to a broad group of borrowers and in that vein ceilings on credit were regarded as potentially creating financial exclusion and increasing illegal lending (Ramsay 2013, p. 101). The new rules do create restrictions on obtaining mortgages and push towards applying lower LTI ratios in order to prevent consumers from falling into arrears with their mortgage payments. ${ }^{32}$

\section{Effectiveness, Supervision, and Enforcement}

Whether the new regime offers an effective response to problems in the mortgage market in terms of achieving "responsible lending," or fewer cases of over-indebtedness, is however hard to determine. Recent data indicate that the number of defaults - which increased after the crisis - has steadily begun to show a downward trend. ${ }^{33}$ Whether that is due to the introduction of a more restrictive regulatory regime for the mortgage market, however, is hard to say. A recovery of the economy may be pointed to as a potential cause (Bank of England 2014).

In the light of continuing developments in the market, it is not strange that new recommendations have already been made since the entry into force of the MMR rules. Notably, with regard to an interest rate stress test, the FPC proposes that it should assess "whether borrowers could still afford their mortgages if, at any point over the first five years of the loan, [the] Bank Rate were to be 3 percentage points higher than the prevailing rate at origination" (Bank of England 2014, p. 52). Further, some points require renewed consideration. For example, although lenders generally seem to favour the flexibility that the new rules still allow, they also point out that this same flexibility can create supervisory problems or enable risk-averse behaviour of lenders that could harm certain groups of borrowers (FSA 2012a, Appendix 1, para. 7). The FCA has the power to enforce the new rules through suspension or restriction of licences to lenders, or through penalties. ${ }^{34}$ The norm that lenders should take account of certain or likely changes in the customer's income or expenditure (rule 11.6.14R) may however be hard to apply in practice. What to do in cases where a customer has a fixed-term contract but an otherwise impeccable credit history and good job prospects? A change in income is in this case foreseeable; however, a lender may find it a commercially sound decision to nevertheless extend credit in these circumstances. One may wonder whether, if the customer falls into arrears, the lender can be considered in breach of the FCA conduct of business rules (Council

\footnotetext{
${ }^{31}$ See rule $11.6 .5 \mathrm{R}(2)$.

${ }^{32}$ Note also the FPC's recommendation that mortgage lenders should limit the proportion of mortgages at high LTI multiples; Bank of England (2014), p. 52.

${ }^{33}$ For statistics on arrears and possessions, see the Council of Mortgage Lenders website: http://www.cml.org.uk/ $\mathrm{cml} /$ media/press $/ 3894$.

${ }^{34}$ FCA Decisions Procedure and Penalties Manual (DEPP).
} 
of Mortgage Lenders 2012, paras. 14-15). More risk-averse lenders may in such circumstances decide to deny credit, which is likely to harm certain consumer groups, such as those who are self-employed or on fixed-term contracts. Stricter duties of responsible lending may therefore overshoot their goal in respect of certain potential borrowers. Revision may at some point be required.

Importantly also, regulatory policies, in combination with other government interventions, often have wider effects on the housing market. ${ }^{35}$ Even if post-crisis policy interventions have helped the UK housing market recover faster than other (e.g., the Dutch) housing markets, it has been pointed out that they come with significant effects on the market. For example, demand for owner-occupied housing is likely to drop, whereas an increase may be expected in demand for private rentals. To support such expectations, it is necessary for the government to keep a close eye on the availability of such housing in the market and, where possible, to intervene (Scanlon and Elsinga 2014, p. 358). Regular monitoring and possible revision of regulation and other policy interventions will be required.

\section{The Dutch Comparison: More Detailed Modalities for "Responsible Lending"36}

The comparison with the Netherlands shows that under its "responsible lending" policy, which is mainly aimed at preventing over-indebtedness of consumers, the rules were already stricter than in the UK in pre-2007 regulation. Most notably, more precise rules have been in place to assess affordability of credit or "creditworthiness." Also, the restrictions on lending in cases where a consumer fails the creditworthiness assessment have been greater than in the UK, as regulation stipulates that a credit provider is in those circumstances prohibited from entering into the credit agreement. ${ }^{37}$ The regulation moreover prescribes a "comply or explain" regime. ${ }^{38}$

This part sketches the development and current structure of the Dutch regime for regulation of the consumer mortgage market. It should be noted that the regulatory framework has a different set-up than in the UK. The provision of mortgage credit to consumers is regulated through both public and private regulations. The most important instruments are the Dutch Financial Supervision Act (Wet op het financieel toezicht-Wft) and accompanying regulations, and the Code of Conduct for Mortgage Loans (Gedragscode Hypothecaire Financieringen-GHF). ${ }^{39}$ According to its wording, the GHF is in essence voluntary in nature: It governs mortgage loans offered and/or advanced by mortgage lenders that have entered into "the agreement for the self-regulation of a mortgage loan." lenders subscribe to the GHF, its norms can be considered common knowledge in practice: The lenders have set a norm for the market and the industry considers the norms as guiding

\footnotetext{
35 Important is also Sarah Nield's finding that "common sense" approaches to affordability in the mortgage sale process is of limited utility unless it is matched with fitting approaches to the consequences of mortgage default and overall housing policy. See Nield (2015).

${ }^{36}$ I gratefully acknowledge the collaboration of Marie-Claire Menting on this part of the article.

37 Art. 4:34 Wet op het financieel toezicht (Wft).

${ }^{38}$ See below, p. 17.

${ }^{39}$ The Code and explanatory notes can be downloaded at, for instance, www.nvb.nl/publicaties/1671/ gedragscode-hypothecaire-financieringen.html (Dutch and English version of the Code available).

${ }^{40}$ Art 1 in conjunction with art 2 GHF. Cf. Kerste et al. (2011), p. 55. The scope of the GHF also extends to mortgage brokers; see Art 17 of the GHF.
} 
principles (AFM 2007, p. 40; Kerste et al. 2011, p. 55). Whereas the GHF until recently was the most important source of rules on creditworthiness assessments, it has recently been superseded by legislation.

\section{The Financial Supervision Act and the GHF}

The interplay between the GHF and public regulation and supervision takes place through the open norm of responsible lending laid down in Art. 4:34 of the Dutch Financial Supervision Act $(W f t)$. The first section of the article sets out, in short, the obligation for offerors of credit to obtain information on the financial position of the consumer before concluding a credit contract or before substantially raising the credit limit or the sum of the loans. On the basis of this information, the offeror has "to assess, in order to prevent overextension of credit to the consumer, whether concluding the contract would be justified." ${ }^{41}$ Art. 4:34 sub 2 stipulates, in short, that no credit contract is to be concluded and no substantial raise of the credit limit or the sum of the loans is to be granted "where this would not be justified with a view to overextension of credit to the consumer." 42 Art. 4:34 has been elaborated further in Artt. 113-115 Besluit Gedragstoezicht ondernemingen Wft (BGfo). With regard to the GHF, Art. $115 \mathrm{sub} 1 \mathrm{BGfo}$ is of particular relevance, stipulating that in order to prevent overextension of credit, an offeror of credit has to set criteria to assess the application for credit of a consumer. The GHF contains such criteria, as will be described in more detail below.

The essence of Art. 4:34 Wft is that the lender is responsible for assessing whether the credit is affordable for the consumer, at the moment when the credit agreement is concluded as well as for extensions of credit during the term of the loan (AFM 2009, p. 14; Kerste et al. (2011), p. 57). Apart from the rules set in the BGfo, the open norm of responsible lending has not been substantiated by the legislature. The legislature indicated that it is in the first instance up to the offeror of credit to do so, which led to the mortgage lending industry adding specifications of the open norm in the GHF (Dijkhuizen and Caria 2013, p. 117; Netherlands Minister of Finance 2009; C. F. J. van Tuyll 2010, p. 31). Although both the Netherlands Authority for the Financial Markets (AFM) and the legislature generally value the selfregulatory system to prevent overextension of credit, they have on several occasions pressured the industry to tighten the norms of the Code in response to poor lending practices that had led to financial risks for consumers and insufficient compliance with elements of the Code (AFM 2007, pp. 487 ff.; Roelofsen 2011; Van Boom 2012, p. 271). The AFM, which supervises compliance with the Wft and hence enforces Art. 4:34 Wft, has also specified more detailed criteria for responsible lending to consumers in the context of mortgage credit (AFM 2009, pp. 14-15), with reference to the GHF.

The GHF, besides prescribing which (pre-contractual) information has to be provided to consumers, also sets out the criteria to be used to assess the borrowing capacity of a consumer. ${ }^{43}$ The central norm in this respect is formulated in Art 6 sub 1 of the GHF: "The

\footnotetext{
${ }^{41} \mathrm{Cf}$ the translation of Art 4:34 sub $1 \mathrm{Wft}$ on www.rijksoverheid.nl/documenten-en-publicaties/brieven/2009/11/ 16/engelse-vertaling-van-de-wft.html. Art. 4:34 in its current form stipulates also that the same rules apply to the extension of an existing credit agreement.

42 Ibid.

${ }^{43}$ Art. 4:33 sub $1 \mathrm{Wft}$ contains, in short, a general duty to provide (pre-contractual) information. It is however not applicable to mortgage credit lenders (cf. Art 111 BGfo) since the issue of pre-contractual information is regulated by the European Code of Conduct, which is incorporated in the GHF. See Tuinstra and Giphart (2013), p. 298.
} 
mortgage lender shall assess individually every application by a borrower for a mortgage loan on the basis of the borrower's financial position and credit status and the value of the offered collateral, including the residence that is to serve as collateral for the repayment of the mortgage loan." The framework for assessing whether and to what amount giving a mortgage loan can be considered responsible is therefore based on two elements: the income of the borrower (the LTI ratio) and the market value of the residence (the LTV ratio).

At this level, the rules are quite similar to the UK rules after the MMR. However, further detail is added to the Dutch rules: The maximum amount of the gross expenses linked to a mortgage loan is to be determined upon the current housing costs set by the National Institute for Family Finance Information (NIBUD). Under certain circumstances, it is possible to obtain a higher loan than the maximum amount stipulated by GHF. At this point, the GHF has a "comply or explain" nature. The possibilities to deviate from the norms exist in certain welldefined cases. Additionally, a qualitative explain clause exists: Deviation from the rules on borrowing capacity is possible in exceptional cases provided that, inter alia, the reasons for deviating are recorded and substantiated (Art 6.10 GHF). In practice, the "explain" mortgage was used quite often until 2008 but use of it has since subsided with the introduction of restrictions by the supervisory authority, the AFM. Since then, the number of "explain" mortgages has dropped from $30 \%$ in $2007-2008$ to $10 \%$ in 2009 (Kerste et al. (2011), pp. ii and $\mathrm{xi}$ ).

\section{Temporary Rules on Mortgage Credit}

On 1 January 2013, however, the regulatory landscape for the mortgage credit market changed with the enactment of the Temporary rules on mortgage credit (Tijdelijke regeling hypothecair krediet). ${ }^{44}$ As of this date, the formulation of criteria for the assessment of the borrowing capacity of a consumer is no longer a predominantly private matter. ${ }^{45}$ The rules laid down by the ministerial regulation concern the norms to be taken into account by a mortgage lender when assessing the borrowing capacity of a borrower for a mortgage loan. ${ }^{46}$ As such, the regulation covers a topic that was formerly regulated by the GHF. Since the legislature took, inter alia, the rules of the GHF into account while drafting the regulation, the provisions of the regulation show a considerable overlap with the rules on borrowing capacity set out by the GHF. Not only do both the regulation and the GHF stipulate which income criteria are to be applied when assessing an application by a borrower for a mortgage loan (LTI ratio), both regulatory frameworks also set a ratio between the maximum amount of mortgage credit that can be granted and the value of the residence (LTV ratio). Maximums are now set at a LTV ratio of $106 \%$ and this ratio will be lowered with 1 percentage point per year until it reaches and stays at $100 \%$ from 2018 onwards. ${ }^{47}$ The regulation as well as the GHF allow for deviation from these rules in well-delineated cases. ${ }^{48}$ Some of the GHF provisions on borrowing capacity thus became legally enshrined.

\footnotetext{
${ }^{44}$ Netherlands Government Gazette 2012, no. 26433. For amendments to these rules as of $1 / 1 / 2014$, see Parliamentary Papers II 2013/14, 32847, no. 98.

${ }^{45}$ Cf. Art. 115 sub 1 BGfo.

46 The regulation is an implementation of Art $115 \mathrm{sub} 3$ BGfo which reads that income criteria and the maximum amount of mortgage credit in relation to the value of the residence are to be laid down by ministerial regulation.

${ }^{47}$ Temporary rules on mortgage credit, Art. 5.

${ }^{48}$ Netherlands Government Gazette 2012, no. 26433, 6.
} 
The reason for laying the income criteria down by regulation was found in the lack of clarity that existed on the mortgage market as regards the interpretation of the income criteria for 2012 due to an announcement of the AFM. In 2012, the AFM notified the banks that in its opinion, the NIBUD norms for double-income households with a total income between 30000 and 40000 euros could not be considered as "responsible lending" in advance. The legislature decided to intervene and to lay down the income criteria by regulation, in order to prevent any future confusion on the norms that have to be applied by mortgage lenders to assess an application for mortgage credit. Art. $115 \mathrm{sub} 4$ BGfo stipulates that mortgage lenders have to apply the criteria set out in the Temporary rules on mortgage credit, in addition to the criteria set by themselves (cf. Art. 115 sub 1 BGfo). ${ }^{49}$

The phrase "in addition" implies that the GHF did not cease to exist. The norms set out by the Temporary rules are minimum norms. Mortgage lenders thus have the possibility to apply more stringent norms. ${ }^{50}$ The enactment of the Temporary rules however will lead to a revision of the GHF to prevent double rules. The self-regulatory provisions that have become legally enshrined will be deleted. Up until that has been done, the Temporary rules take precedence over the $\mathrm{GHF}^{51}$

\section{Effectiveness, Supervision, and Enforcement}

It may be that stricter regulation is a logical follow-up to a financial crisis, with the government seeking to obtain new control over the housing market. From that perspective, government intervention (partly) replacing self-regulation in the Netherlands is not surprising. It also means that supervision of the rules is placed more firmly in the hands of the AFM, who before the introduction of the Temporary rules indirectly (i.e., through the open norm of Art. 4:34 Wft and Artt. 113 ff. BGfo) supervised compliance with the GHF as part of its task to monitor conduct in the financial markets (AFM 2007, pp. 40-41; AFM 2009, p. 15; Van Boom 2012, p. 271).

For rules to be effective, however, it is not just important to know that they achieve their set goals but also that they do not overshoot those goals and go further than is necessary to achieve them, potentially even imposing unnecessary restrictions on borrowers (Kerste et al. 2011, p. xii). One wonders whether the rules that have been developed post-crisis manage to strike the right balance. Dutch rules seem to have become more restrictive than need be if one considers the relatively low default on payments of Dutch borrowers in comparison to other countries (Kerste et al. 2011, p. 28). As indicated in "Responsible Lending Policies: Concept and Context", the real motivation of the legislator appears to be to push down the existing, very high household debt ratio. An effect of the new rules, however, might be that it becomes more difficult for certain borrowers to obtain mortgages, an effect that may be reinforced by proposed adjustments to the NIBUD norms relating to the costs of housing. ${ }^{52}$ Like in the UK, this may result in a greater demand for rental housing - a development that may require

\footnotetext{
${ }^{49}$ Netherlands Government Gazette 2012, no. 26433, 6; Bulletin of Acts and Decrees 2012, 695, 97; Parliamentary Papers II 2013/14, 32 847, no. 32. Cf. also Tuinstra and Giphart (2013), p. 299, and www.afm.nl/nl/ nieuws/2012/jan/verruiming-leencapaciteit-tweeverdieners.aspx for the press release of AFM on the NIBUD norms concerned.

${ }^{50}$ Netherlands Government Gazette 2012, no. 26433, 6.

${ }^{51}$ www.nvb.nl/nieuws/2012/1639/tijdelijke-regeling-hypothecair-krediet.html.

52 “Duurder huis, minder lenen”, NRC Handelsblad, 21 november 2014, p. 4; see also http://www.nrcq.nl/2014/ 11/21/je-kunt-straks-minder-lenen-en-wat-er-nog-meer-gaat-veranderen-op-de-woningmarkt.
} 
monitoring and intervention by the government to ensure that housing expectations are met. ${ }^{53}$

Whichever way that assessment is made, the question remains how the EU Mortgage Credit Directive will fit into the existing regimes found in the Member States and whether it can contribute to a responsible lending policy in both Member States. It is now time to return to this question.

\section{Introducing the EU's Responsible Lending Policy in Dutch and UK Regulation}

The EU Consumer Mortgage Credit Directive, as indicated, contains a minimum harmonization provision (Art. 18) which obliges Member States to maintain or introduce rules that oblige lenders to carry out creditworthiness assessments on borrowers. Looking at other elements of a "responsible lending" policy, ${ }^{54}$ the Directive for a large part draws on the norms on conduct of business in the Consumer Credit Directive ${ }^{55}$ and creates a similar framework for mortgage credit, taking into account the specificities of mortgage credit where appropriate. ${ }^{56}$ The rules concern financial education of consumers (Art. 6), information and practices preliminary to the conclusion of the credit agreement (Art 10. Ff.), the annual percentage rate of charge (Art 17.), the creditworthiness assessment (Art. 18 ff.), database access (Art. 21), advice (Art. 22), early repayment (Art. $25 \mathrm{ff}$ ), and prudential and supervisory requirements (Art. $29 \mathrm{ff}$.). As said earlier, the provisions of the Directive are for the most part aimed at minimum harmonization, apart from those relating to the standardized information provided through the ESIS and the information concerning the annual percentage rate of charge (APRC) which aim for full harmonization (see Art. 2). It is noteworthy that the introduction of the ESIS for UK lenders signals a change. Until now, certain information has been provided through a Key Facts Illustration (KFI). The ESIS requires more information to be provided and in a different format. To facilitate the transition to the new format, the UK government has negotiated an extension with the European Commission which means that lenders will need to have transferred to the new format by March 2019 (instead of March 2016). ${ }^{57}$ Also, it may be that explanations given to consumers before the lender has assessed their financial situation and their creditworthiness will need to be adapted after such an assessment is made, and in good time before the credit agreement is signed, albeit that no separate document needs to be drawn up. ${ }^{58}$

Another important feature of the Directive is that it prescribes a strict creditworthiness assessment. ${ }^{59}$ Such an assessment fits with the aim of preventing over-indebtedness that the EU pursues and is often considered a cost-effective tool since lenders have developed longstanding experience with screening and monitoring of clients (see, e.g., Domurath 2015;

\footnotetext{
${ }^{53}$ See "The Dutch Comparison: More Detailed Modalities for 'Responsible Lending,".

54 See "Introduction".

${ }^{55}$ Directive 2008/48/EC on credit agreements for consumers [2008] OJ L133/66.

${ }^{56} \mathrm{COM}(2011) 142$ final, 4.

${ }^{57} \mathrm{http} / /$ www.addleshawgoddard.com/view.asp?content id=7360\&parent id=6606.

${ }^{58}$ CJEU 18 December 2014, Case C-449/13 CA Consumer Finance SA v̄. Bakkaus and Bonato, nyr, paras 4547.

${ }^{59}$ Like the Consumer Credit Directive in Art 8. Notably, lenders who do not carry out a creditworthiness assessment may be liable to penalties, such as losing the right to claim interest, which may then not be replaced by statutory interest; see CJEU 27 March 2014, Case C-565/12 LCL Le Crédit Lyonnais SA v. Kalhan, nyr, para 55.
} 
Atamer 2011). The creditworthiness assessment focuses in particular on the ability of the borrower to repay the loan. To that end, the lender should assess (and verify!) the ability of the borrower to repay the loan over his lifetime, taking account in particular of future payment or interest increases. If the Court of Justice of the EU (CJEU)'s approach to the creditworthiness assessment under the Consumer Credit Directive is followed, this would however not preclude the lender from making that assessment on the basis solely of information supplied by the consumer, "provided that that information is sufficient and that mere declarations by the consumer are also accompanied by supporting evidence." ${ }^{60}$ Further, the affordability of the credit "should be considered in the light of other regular expenditure, debts and other financial commitments as well as income, savings and assets." 61 The Directive emphasizes moreover that whilst the LTV factor is important in the assessment, the main focus should be on the ability of the consumer to repay the credit. The possibility of value increases of the property should therefore not be the determinative element. ${ }^{62}$ Moreover, account should be taken of (at the time of concluding the credit agreement) future events that may influence the borrower's ability to repay the loan, such as loss of income or, where applicable, an increase in the borrowing rate or a negative change in the exchange rate. ${ }^{63}$

The duty to assess the borrower's creditworthiness is combined with a duty to deny credit if the consumer does not fulfil it. Although not explicitly phrased like this in the UK rules, it would seem that the affordability assessment laid down in rule 11.6.5 of the MCOB prescribes a similar approach. Significantly different from before in the UK, the new regulation therefore places a duty on lenders to deny credit where consumers do not fulfil the creditworthiness assessment. Dutch law already contained such a duty in Art. 4:34 sub $2 \mathrm{Wft}^{64}$

How do the Directive's new rules more specifically contribute to responsible lending policies in the UK and the Netherlands? As has been seen, different regulatory choices in these Member States are informed by the sources of risk that regulators seek to control, for example household debt ratios. These choices will also colour the way in which the EU Directive's responsible lending policy is translated into national laws. In all likelihood, the modalities of that policy will remain very different from one jurisdiction to another. If we just focus on LTI and LTV ratios as modalities for assessment, the following can be observed.

Looking at the Netherlands, the way in which loans are assessed is considered to be an important attributing factor to the low rate of defaults on mortgages in the Netherlands. In particular the focus on LTI as an element of the creditworthiness assessment of borrowers is regarded as an important contribution towards responsible lending, as it is supposed to be a better indicator of borrowers' ability to repay their loan than the LTV assessment (Kerste et al. 2011, p. 28-29). LTI requirements are correspondingly strict in Dutch regulation: Fixed ratios are set by the NIBUD norms and the Temporary rules on mortgage credit. Furthermore, they apply in a "comply or explain" manner, meaning that divergence from these ratios is only possible if the lender can verify that the borrower will be able to repay the loan. ${ }^{65}$

The UK, until recently, did not strictly regulate LTI requirements apart from the more general guidance provided by the OFT. The post-MMR framework shows that LTI

\footnotetext{
$\overline{{ }^{60} \text { CJEU CA Consumer Finance } S A}$, para 39. The Court also holds that the creditor is not required to carry out systematic checks of the veracity of the information supplied by the consumer.

${ }^{61}$ Mortgage Credit Directive, recital 55.

${ }^{62}$ Mortgage Credit Directive, recital 55 and Art. 18(3).

63 Ibid.

${ }^{64}$ See "The Dutch Comparison: More Detailed Modalities for 'Responsible Lending"”.

${ }^{65}$ See above, "The Dutch Comparison: More Detailed Modalities for 'Responsible Lending'”.
} 
assessments have become more important for assessing the affordability of credit for borrowers. It is nevertheless noteworthy that the precise conditions for LTI ratios are not prescribed by the regulator but may be determined by lenders. Although that does not have to be problematic - since lenders also have an interest in minimizing defaults on mortgage payments, in particular where house prices may fluctuate - it means that the control over LTI ratios is not as strictly monitored as it is in the Netherlands. In cases where discretion exists, it may even be hard to determine which decisions will satisfy the supervisory authority.

LTV ratios, secondly, are also used as indicators for creditworthiness assessments and have gained particular significance in policies aimed at restraining household debt. Dutch LTV ratios, as we have seen, appear to be overall higher than those in the UK, since they are in most cases higher than $100 \%$ whereas UK ratios tend to be lower. The fact that these ratios are high in the Netherlands is perhaps the most significant explanation for the country's extremely high household debt ratio. Even if LTI ratios are contained, it does make the financial system more vulnerable to market fluctuations, in particular now that many mortgages are "under water." The Dutch legislator's introduction of (gradually) stricter limitations LTV ratios through the 2012 Temporary rules for mortgage credit is therefore in line with seeking to bring down household debt. Although household debt ratios in the UK are also high, the issue seems less pressing than in the Netherlands (Bank of England 2014, p. 52).

Now placing the EU Mortgage Credit Directive's provisions on the creditworthiness assessment beside the two national regimes, it would appear that both fulfil the requirements of the Directive on a general level. Each regime prescribes modalities for affordability assessments and both include an evaluation of LTI ratios and LTV ratios, albeit with different degrees of precision. Other factors, such as interest increases, other debts and available savings are also generally taken into account. ${ }^{66}$

Turning to the creditworthiness assessment, it seems likely that the factors listed in the Directive may in any event contribute to the effectiveness of the Member States' responsible lending policies by giving an additional boost to regulators to ensure that their policies are in order. However, whether the Directive is going to add significant new substance to these policies has yet to be seen. As we have seen in the comparison of the UK and the Netherlands, the responsible lending policies in both countries have recently been revised to now include detailed and stricter rules, in particular to prevent over-indebtedness. The Directive's generally phrased terms would appear to make it possible to comply with it without introducing many new rules (Giphart 2014). Also, the suspicion is confirmed that the rules of the Directive enable national regulators to still pursue a responsible lending policy that they deem best fitted to their national financial markets. There is for example no hard and fast rule as to how LTI and LTV ratios should be weighed in a creditworthiness assessment. The Directive gives guidance, but otherwise leaves almost any decision to the Member States' regulators. ${ }^{67}$ The UK and the Dutch regimes, although different in many respects, therefore both seem to fulfil the Directive's goals.

Interestingly, nonetheless, the comparison of the two systems reveals several common issues encountered by regulators in the mortgage credit market, which might well provide a basis for further work on a common responsible lending policy. First, in each system, questions have arisen as to whether new regulations do not overshoot their goal. Even if stricter control

\footnotetext{
${ }^{66}$ See Mortgage Credit Directive, recital 55.

${ }^{67}$ Apart perhaps from the rule that construction or renovation of a property can be considered as a ground for assuming a future increase in value of the property; see Mortgage Credit Directive, Art. 18(3).
} 
of LTV and LTI ratios may go some way towards ensuring more responsible credit decisions, stricter regulation also entails that certain groups of borrowers will not be able to obtain a mortgage, or only with much difficulty. ${ }^{68}$ Such reforms are therefore likely to have effects on the housing market, e.g., a decrease in demand of owner-occupied housing (Scanlon and Elsinga 2014). Within the wider institutional framework - such as government schemes to support home ownership or to assist borrowers in difficult times - regulation can thus be an important tool for legislators and policymakers to (purport to) control the housing market. Its effects, such as a likely increased demand for rental housing in the UK and in the Netherlands (Scanlon and Elsinga 2014, p. 358), deserve to be monitored in order to take appropriate action where needed.

Further, the format of rules, in particular whether they allow room for flexibility of lenders in loan decisions, can make it more difficult for the supervising authority to monitor compliance. The Netherlands has adopted a "comply or explain" regime for mortgage lending, in which the benchmark for assessment is provided by the NIBUD norms for costs of housing. That solution can increase compliance and bring down the costs of monitoring compliance, but of course it is preceded by a policy question, namely whether such restrictions are regarded as acceptable. UK lenders have not been willing to concede their flexibility in laying down specific rules for assessing affordability. These diverging approaches also, perhaps on the basis of experiences with both regimes, can provide further testing ground for responsible lending policies.

Finally, from a broader perspective of lawmaking in consumer markets, the regulation of mortgage credit in the UK and in the Netherlands provides interesting examples of the interaction between public regulation and self-regulation. The shift in both systems towards greater regulatory coverage, although in these cases accelerated by a crisis in the housing market, shows how informal norms are turned into formal regulation. As is shown in particular by the Dutch example, regulators are willing to acknowledge norms developed through selfregulation and in their design of new regulation to explicitly take these norms into account. That process is similar to the way in which the EU Mortgage Credit Directive came into being, with the Directive being based on, and adopting rules from, the European Voluntary Code of Conduct on Pre-Contractual Information for Home Loans. ${ }^{69}$ Such processes of interaction, at national and at EU level, indicate that bottom-up emergence of norms could well be indicative for determining an appropriate balance between lender and borrower interests in "responsible lending" (compare Zumbansen 2011). Even though this may take some time.

\section{Conclusion}

The conclusion must therefore be that even though it is possible to distinguish common elements of a "responsible lending" policy at EU level, specific rules remain diverse from one jurisdiction to another. Financial markets have their own, particular characteristics and regulators at (in this case) national levels are free to adjust their responsible lending policies to the sources of risk that they seek to control. In the UK, the focus currently appears to be on

\footnotetext{
${ }^{68}$ On the UK, "The UK Reforms", and on the Netherlands, "The Dutch Comparison: More Detailed Modalities for 'Responsible Lending'".

${ }^{69}$ Agreement on a Voluntary Code of Conduct on Pre-Contractual Information for Home Loans, available at: http://ec.europa.eu/internal_market/finservices-retail/docs/home-loans/agreement_en.pdf. See also European Commission, Commission Recommendation on pre-contractual information to be given to consumers by lenders offering home loans [2001] OJ L69/25.
} 
preventing defaults on mortgage payments whereas the Netherlands seeks to pursue policies that can push down the high level of household debt in the country. Other Member States, although not researched in this article, are likely to have their own and probably again different issues to solve (compare Ramsay 2013 on the UK and France). It could even be fair to say that the Mortgage Credit Directive was probably inspired by the relatively weaker mortgage regulations in southern-European Member States, such as Spain, which might benefit from more robust rules for mortgage lending. Even in times of increasing globalization, some issues remain local.

The comparison of how responsible lending policies are turned into regulation in different legal systems, nonetheless, reveals some aspects that could be of great relevance for future efforts to design responsible lending policies. In relation to the balancing of substantive rules, the design of supervision schemes, and the interaction with views from the industry, law reforms in the UK and the Dutch mortgage markets provide useful directions for testing and adjusting regulation.

Open AccessThis article is distributed under the terms of the Creative Commons Attribution 4.0 International License (http://creativecommons.org/licenses/by/4.0/), which permits unrestricted use, distribution, and reproduction in any medium, provided you give appropriate credit to the original author(s) and the source, provide a link to the Creative Commons license, and indicate if changes were made.

\section{References}

AFM. (2007). Kwaliteit advies en transparantie bij hypotheken. Oriëntatiepunt voor en goede adviespraktijk. Autoriteit Financiële Markten. Available at www.afm.nl/nl/professionals/afm-actueel/rapporten/2007/ kwaliteit-advies-transparantie-hypotheken.aspx.

AFM. (2009). Consultatiedocument toetskader hypothecaire kredietverlening. Autoriteit Financiële Markten. Available at www.afm.nl/ /media/files/consultaties/consultatie-hypotheken/consultatie-documenthypotheken.ashx.

Atamer, Y. M. (2011). Duty of responsible lending: Should the European Union take action? In S. Grundmann \& Y. M. Atamer (Eds.), Financial services, financial crisis and general European contract Law (pp. 179-202). Alphen aan den Rijn: Kluwer Law International.

Bank of England. (2014). Financial stability report. Bank of England, June 2014.

BKR. (2014). BKR Hypotheekbarometer: ruim 100.000 consumenten met een betalingsachterstand op de hypotheek. Bureau Krediet Registratie, 24 April 2014. Available at http://perskamer.bkr.nl/bkrhypotheekbarometer-ruim-100000-consumenten-met-een-betalingsachterstand-op-de-hypotheek/.

Cherednychenko, O. O. (2011). Conceptualising unconscionability in the context of risky financial transactions: How to converge public and private law approaches? In M. Kenny, J. Devenney, \& L. Fox O’Mahony (Eds.), Unconscionability in European private financial transactions (pp. 246-274). Cambridge: Cambridge University Press.

Council of Mortgage Lenders. (2012). Mortgage market review: Proposed package of reforms. Response by the council of mortgage lenders to the financial services authority consultation paper CP11/31. London: Council of Mortgage Lenders.

Dalton, M. (2011). Mortgage burden looms over Dutch. The Wall Street Journal, 5 December 2011.

Dijkhuizen, T. C. A., \& Caria, V. Y. E. (2013). De invulling van financieelrechtelijke open normen in een meerlagige rechtsorde. In C. G. Breedveld-de Voogd, A. G. Castermans, M. W. Knigge, T. van der Linden, J. H. Nieuwenhuis, \& H. A. ten Oever (Eds.), Rechtsvinding in een meerlagige rechtsorde (pp. 109-121). Deventer: Kluwer.

DNB. (2014). Overview of financial stability. De Nederlandsche Bank, Spring 2014. Available at http://www. dnb.nl/en/binaries/OFSuk_tcm47-306230.pdf.

Domurath, I. (2015). A Map of responsible lending and responsible borrowing in the EU and suggestions for a stronger legal framework to prevent over-indebtedness of European consumers. In H.-W. Micklitz \& I. Domurath (Eds.), Consumer debt and social exclusion in Europe (p. 155). Aldershot: Ashgate.

European Commission, Social Situation Observatory. (2010). Research Note 4/2010, Over-indebtedness. 
Expertisecentrum woningwaarde. (2014). Monitor koopwoningmarkt, 2014, 4th quarter. Available at http://www. bk.tudelft.nl/fileadmin/Faculteit/BK/Over_de_faculteit/Afdelingen/OTB/kwartaalrapportage_monitor_ koopwoningmarkt/2014 4 Kwartaalrapportage Monitor Koopwoningmarkt/Kwartaalrapportage Monitor_Koopwoningmarkt_2014-4.pdf.

FSA. (2012a). PS12/16, mortgage market review. London: Financial Services Authority.

FSA. (2012b). Supplement to PS12/16, Mortgage Market Review Data Pack. London: Financial Services Authority.

Giphart, N. M. (2014). De Richtlijn woningkredietovereenkomsten: een Europese oplossing voor de crisis op de woningmarkt? Nederlands Tijdschrift voor Europees Recht, 139-146.

Kerste, M., Risseeuw, P., Baarsma, B., \& Rosenboom, N. (2011). Publieke belangen en hypotheekregulering (pp. 2011-2019). Amsterdam: SEO Economisch Onderzoek.

Mak, V. (2013). The "average consumer" of EU law in domestic and European litigation. In D. Leczykiewicz \& S. Weatherill (Eds.), The involvement of EU law in private law relationships (pp. 333-356). Oxford: Hart Publishing.

Mian, A., \& Sufi, A. (2014). House of debt. Chicago: Chicago University Press.

Netherlands Minister of Finance. (2009). Letter of the Minister of Finance with responses to Parliamentary questions. 18 May 2009, reference FM/2009/960 U.

Nield, S. (2012). Mortgage finance: Who's responsible? In J. Devenney \& M. Kenny (Eds.), Consumer credit, debt and investment in Europe (pp. 160-181). Cambridge: Cambridge University Press.

Nield, S. (2015). Mortgage market review: "Hard-wired common sense"? Journal of Consumer Policy, published online 7 March 2015. Available at http://link.springer.com/article/10.1007/s10603-014-9280-2\#.

OECD statistics. (n.d.). available at http://stats.oecd.org/Index.aspx?DataSetCode=FIN_IND_FBS\#.

OFT. (2009). Second charge lending - OFT guidance for lenders and brokers. Office of Fair Trading, July 2009. Available at: http://webarchive.nationalarchives.gov.uk/20140402142426/http://www.oft.gov.uk/shared_oft/ business leaflets/general/oft1105.pdf.

OFT. (2010/2011). Irresponsible lending - OFT guidance for creditors. Office of Fair Trading, March 2010 (updated February 2011). Available at: http://webarchive.nationalarchives.gov.uk/20140402142426/http:// www.oft.gov.uk/shared_oft/business_leaflets/general/oft1107.pdf.

Oxera. (2010). An assessment of the FSÄ's proposed rules for mortgages. A report prepared for the council of mortgage lenders. Oxford: Oxera Consulting Ltd.

Ramsay, I. (2013). Culture or politics? Models of consumer credit regulation in France and the UK. In T. Wilson (Ed.), International responses to issues of credit and over-indebtedness in the wake of the crisis (pp. 79107). Farnham: Ashgate.

Rinaldi, L., \& Sanchez-Arellano. (2006). A. Household debt sustainability. What explains household nonperforming loans? An empirical analysis. European Central Bank, Working Paper Series No. 570.

Roelofsen, E. P. (2011). Overkreditering na de aangepaste gedragscode: much ado about nothing? Tijdschrift voor Financieel Recht, 196-204.

Scanlon, K., \& Elsinga, M. (2014). Policy changes affecting housing and mortgage markets: How governments in the UK and the Netherlands responded to the GFC. Journal of Housing and the Built Environment, 29, 335-360.

Tuinstra, H. C., \& Giphart, N. M. (2013). Zorgplicht bij hypotheekadvies en hypotheekverstrekking. Tijdschrift voor financieel recht, 293-301.

Van Boom, W. H. (2012). Hypothecair krediet aan consumenten - een overzicht. Tijdschrift voor Consumentenrecht en Handelspraktijken, 2012-6, 268-278.

van Tuyll, C. F. J. (2010). Enkele AFM-boetebesluiten ter zake van overkreditering langs de lat van het bepaaldheidsgebod. Onderneming en Financiering, 20(2), 30-38.

World Bank (2013). Responsible lending_overview of regulatory tools. Available at http://siteresources. worldbank.org/EXTGLOBALFINREPORT/Resources/8816096-1361888425203/90620801364927957721/9115725-1384205223659/Responsible_Lending_Paper.pdf.

Zumbansen, P. (2011). Neither "public" nor "private", "national" nor "international": Transnational corporate governance from a legal pluralist perspective. Journal of Law and Society, 38, 50-75. 